\title{
Вадзім Шклярык
}

Нацыянальная акадэмія навук Беларусі, Мінск

\section{Роля мікратапаніміі ў выяўленні семантыкі мясцовых апелятываў (на ўсходнепалескім матэрыяле)}

\section{1. Уводзіны}

Пры аналізе назваў дробных геаграфічных аб’ектаў у кірунку «ад апелятыва да оніма» часам маюць месца выпадкі некаторай неадпаведнасці паміж вядомай семантыкай утваральнай базы і дэнататам адпаведнага ўласнага наймення. Абумоўлена гэта можа быць у тым ліку няпоўнымі звесткамі пра значэнні і семантычныя адценні апелятыва ў мясцовых гаворках. Таму для выяўлення больш поўнай семантыкі такога слова карысным з'яўляецца адваротны кірунак аналізу згаданай пары - «ад оніма да апелятыва», i ўсходнепалескі матэрыял дазваляе прадэманстраваць гэта на канкрэтных прыкладах.

\section{2. Апелятыў старына}

Спецыфічнай у плане семантыкі і тэрыторыі распаўсюджання з'яўляецца лексема старына́ (памянш. старь́нкка), якая адзначаецца толькі на поўдні Усходняга Палесся. Так, на Мазыршчыне 1 ўказанае слова зафіксавана ў значэннях 'месца, дзе раней было поле', 'старое поле', 'запушчаная, спустошаная зямля’ [Иванова 2007: 185], у межах Тураўскага Палесся' і на поўдзень ад яго - 'поле, на якім зрэдку сеюць' [Лексіка гаворак Беларускага Прыпяикага Палесся 2008: 281]. Што датычыць Случчыны і ўвогуле арэала

${ }^{1}$ Пад Мазыршчынай і Мазырскім Палессем маецца на ўвазе тэрыторыя, мікратапанімія якой даследавалася Г. А. Івановай [Иванова 2007].

2 Пад Тураўшчынай і Тураўскім Палессем разумеецца тэрыторыя, лексічны склад гаворак якой знайшоў адлюстраванне ў «Тураўскім слоўніку» [Тураўскі слоўнік 1982-1987].

${ }^{3}$ Пад Случчынай у дадзенай рабоце маецца на ўвазе тэрыторыя Любанскага, Салігорскага, Слуцкага і Старадарожскага раёнаў Мінскай вобласці і Глускага раёна Магілёўскай вобласці. 
слуцкіх гаворак, то тут выяўлена толькі адна фіксацыя апелятыва старына - 'поле сярод лесу здаўна' (Ст.-дар.) [Яшкін 2005: 629]. У той жа час суадносныя 3 ім мікратапонімы з'яўляюцца ў гэтай мясцовасці, а таксама на тэрыторыі сумежжа слуцкіх і мазырскіх гаворак шырокавядомымі: Cmapынá урочышча (Ямінск Люб., Старобін Саліг.) Жытк., Баянічы Люб., Шапчыцы Ст.-дар.), частка вёскі (Залессе Петр.), поле (Лучыцы Петр.), лес, поле (Языль Ст.-дар.), Стары́нка балота, лес (Гаць Акц.), поле (Ляды Ст.-дар.), лес (Ляўкі Ст.-дар.); Старына́ урочылича (Вольніца Глус.) [Мікратапанімія Беларусі 1974: 228], Старыз нь́ поле (Кольна Жытк.) [Вярэніч 2009: 395], Старынка заліўны луг (Грохаў Лоеўскі) [Беларуская мова 1997: 157], Застарынне забалочанае месца (Чорныя Брады Акц.) [Беларуская мова 1996: 190], Падстарына (Ляхава Слуц.) [Адамовіч 1971: 25], Бліюняя Старына́ і Да́льняя Старына́ палі (Зялёная Дуброва Ст.дар.) [Лемцюгова 1970: 31], Папова Старына забалочанае месца (Івашкавічы Петр.) [Беларуская мова 1993: 135] і некаторыя іншыя. На Мазыршчыне адпаведных найменняў параўнальна менш [Мікратапанімія Беларусі 1974: 97; Беларуская мова 1992: 143; Беларуская мова 1993: 104; Беларуская мова 1996: 171; Иванова 2007: 185], на Тураўшчыне ж выяўлена толькі адна назва [Вярэніч 2009: 254], прычым утворана яна можа быць ад айконіма.

Такая розніца ў колькасці мікратапонімаў у межах Усходняга Палесся сведчыць пра выхад апелятыва старына з актыўнага ўжытку і яго анімізацыю ў тых мясцовасцях, дзе адпаведныя найменні прадстаўлены найбольш шырока (у прыватнасці, на Случчыне). У той жа час звяртае на сябе ўвагу ўжыванне ў паўднёвых раёнах Гомельскай вобласці такіх мікратапонімаў для называння водных аб'ектаў: Cmapына́ старыца (Роза Люксембург Ельскі) [Беларуская мова 1992: 143], Старына рэчка (Аляксандраўка Нараўл.) [Беларуская мова 1996: 248], Старына старое рэчышча 3 вадой (Лоеў) [Беларуская мова 1997: 157], Старьінкі сажалка (Бячанская Буда Жытк.) [Беларуская мова 1989: 172], Старынкі возера (Балажэвічы Маз.) [Беларуская мова 1996: 171]. Гэта дазваляе меркаваць пра наяўнасць у лексемы старына яшчэ аднаго значэння - 'старое рэчышча' і разглядаць яе ў якасці сіноніма да вядомых у мазырскіх гаворках слоў стары́к і ста́рыци [Дарошка 1992: 74; Лексічны атлас беларускіх народных гаворак 1994, № 80]. А паколькі ў старабеларускай мове апелятыў старына такой семантыкі не меў [Гістарычны слоўнік беларускай мовы 2012: 335], то выведзенае намі на падставе аналізу мясцовых мікратапонімаў значэнне з’яўляецца пазнейшым, другасным, развілося яно, відаць, толькі ў асобных гаворках краю.

4 Мікратапонімы, прыведзеныя без спасылак, узяты або з асабістага архіва аўтара, або з дыялекталагічнага архіва кафедры беларускага мовазнаўства БдПУ імя Максіма Танка. Усе айконімы падаюцца ў адпаведнасці з нарматыўнымі даведнікамі 3 серыі «Назвы населеных пунктаў Рэспублікі Беларусь» (2003-2010), згодна з адлюстраваным у іх адміністрацыйнатэрытарыяльным падзелам краіны. 


\section{3. Апелятыў гной і вытворныя}

Вядомая практычна на ўсёй тэрыторыі Беларусі лексема гной 'перапрэлая сумесь памёту свойскай жывёлы і подсцілу, якая служыць для ўгнаення глебы' [Дьялекталагічны атлас беларускай мовы 1963, № 284; Тлумачальны слоўнік беларускай мовы 1978: 64] у мікратапаніміі Усходняга Палесся знайшла адлюстраванне апасродкавана - у выглядзе вытворных апелятываў. Адным 3 іх з'яўляецца слова пагно́й. Як і адпаведныя назвы дробных геаграфічных аб’ектаў, гэты апелятыў ужываецца не на ўсёй усходнепалескай тэрыторыі: яго арэал - Мазыршчына, Тураўшчына і навакольныя раёны ў межах Гомельскай і Брэсцкай абласцей. Аднак калі ў Тураўскім Палессі і суседнім Петрыкаўскім раёне лексема пагной мае адно значэнне - 'угноенае поле' [Тураусккі слоўнік 1985: 80; Станкевіч, Воінава, Мінакова 2008: 178; Лексіка гаворак Беларускага Прыпяикага Палесся 2008: 271] і этымалагізацыя суадносных $з$ гэтым словам мікратапонімаў Пагно́й поле (Хуснае Петр.); Погно́й сенажаць (Альшаны Стол.) [Тураўскі слоўнік 1987: 380] пытанняў не выклікае, то ў Мазырскім Палессі сітуацыя іншая. Апелятыў пагной тут мае два значэнні: 'зямля, якая на працягу многіх гадоў добра ўгнойваецца' [Иванова 2007: 142] і 'поле, якое некалькі гадоў не апрацоўвалася' [Лексіка гаворак Беларускага Прыпяикага Палесся 2008: 271], што варта ўлічваць пры ўстанаўленні паходжання адпаведных назваў дробных геаграфічных аб'ектаў, якіх на Мазыршчыне параўнальна шмат [Иванова 2007: 141-142 і інш.].

Што датычыць назвы поля Прыгно́iия (было балота (інфарм.). Горкі Ст.дар.), то апелятыўны адпаведнік гно́iй для яе (як і мікратапонім Гно́iйа ва Усходнім Палессі, што дазволіла б дапусціць трансанімізацыю з далучэннем прэфікса) у даступных пісьмовых крыніцах, якія ўтрымліваюць звесткі пра лексічны склад гаворак краю, выявіць не ўдалося, пра такі апелятыў можна меркаваць толькі на падставе словаўтваральнага аналізу наймення. Так, пры дапамозе суфікса -іц- $a$ ад субстантыва можа быць утвораны неасабовы назоўнік, які абазначае прастору на аснове сумежнасці з утваральным словам [Сцяцко 1977: 158]. У нашым выпадку - гной $+-i u-a \rightarrow$ гноіца як угноенае месца, участак, дзе ёсць гной.

Разам 3 тым каментарый інфарманта, атрыманы падчас фіксацыі мікратапоніма Прыгноіща (пра тое, што на месцы поля раней было балота), а таксама існаванне ва Усходнім Палессі такіх найменняў, як Гнойнае Балота (варыянт назвы Гнілое Балота) (Пагоннае Хойн.) [Беларуская мова 1987: 144], Гнойнае Балота (Гнойное Болото) (Старое Высокае Ельскі) [Беларуская мова 1992: 130], дазваляюць меркаваць пра наяўнасць у мясцовых гаворках яшчэ аднаго значэння слова гной, не зафіксаванага ў слоўніках і атласах другой паловы XX - пачатку XXI стст., - 'твань, гніль'. Мяркуючы па ўсім, лексема менавіта 3 такім семантычным напаўненнем 
знайшла адлюстраванне ў прыведзеных вышэй назвах дробных геаграфічных аб'ектаў. Больш за тое, падобнае значэнне, прымаючы пад увагу дэнататы мікратапонімаў, мог мець таксама апелятыў пагной, што лёг у аснову найменняў Пагной возера (Перароўскі Млынок Жытк.) [Беларуская мова 1989: 167], Пагной балота (Боруск, Лукі, Ніканава Калінк.) [Беларуская мова 1993: 101], Пагной (Погной) высахлае возера (Мальцы Нараўл.) [Беларуская мова 1996: 240], Пагноі балота (Вуглы Акц.) [Беларуская мова 1996: 201] i іншых. Апошняе пацвярджаецца фіксацыяй у першай палове XX ст. на тэрыторыі сучаснага Лунінецкага раёна слова пагной у значэнні 'возера, якое зарастае расліннасцю’ [Ossowski 1992: 105].

\section{4. Апелятыў драніна}

Выклікае складанасці таксама этымалагізацыя суадносных 3 лексемай драніна мікратапонімаў Драніна́ лес (дралі, рабілі дахі (інфарм.). Забалацце Акц.); Дра́ніны лес (Глінка Петр.) [Вярэніч 2009: 420], Драні́ны мясціна ў лесе (даўней тут дралі мох (інфарм.). Масцішча Глус.) [Слоўнік мікратапонімай Магілёуиччыны 2004: 67], Удра́ніно лес (Брынёў Петр.) [Вярэніч 2009: 419]. Нягледзячы на наяўнасць ва Усходнім Палессі слоў дрэ́нына 'цаліна' (Галоўчыцы Нараўл., Забалацце Маз.) [Выгонная 1968: 100], дрэны́на 'упершыню апрацаваная зямля' (Казловічы Калінк.) [Лексіка гаворак Беларускага Прыпяикага Палесся 2008: 259], атрыманыя ад інфармантаў каментарыі наконт паходжання некаторых з указаных назваў даюць падставы гаварыць пра іншую семантыку ўтваральнага апелятыва. Адзначаны на Тураўшчыне дзеяслоў драць мае акрамя значэння 'разворваць цаліну' і такое - 'рабіць дранку' [Тураўскі слоўнік 1982: 39]. У гаворках Усходняга Палесся слова дра́нка (дра́нька, дрань, дор, дра́ніu̧а) абазначае 'тонкія дошчачкі, прызначаныя для крыцця страхі' [Лексічны атлас беларускіх народных гаворак 1998, № 86], а таксама 'матэрыял (для пляцення кошыкаў)' [Беларуская мова і мовазнауства 1975: 254], 'дрэўкі, якія прызначаліся для асвятлення’ [Лексічны атлас беларускіх народных гаворак 1997, № 104]. Таму верагодна, што месцы ў лесе, дзе жыхары навакольных вёсак дралі для гаспадарчых патрэб дошчачкі або мох, таксама называліся дранінамі. Пазней, замацаваўшыся за канкрэтнай мясцінай, гэтае слова магло перайсці ў разрад онімаў.

Разам з тым паходжанне зафіксаванай на Мазыршчыне назвы ўрочышча Драніна даследчыца мясцовай мікратапаніміі Г. А. Іванова звязвае ўсё ж 3 апелятывамі, што абазначаюць 'упершыню распрацаваны ўчастак' [Иванова 2007: 67]. I хоць лексема драніна, па даных вучонай, у мясцовых гаворках адсутнічае (што супярэчыць прыведзеным вышэй звесткам пра факты фіксацыі ўказанага слова на гэтай тэрыторыі), этымалагізацыя 
адзначаных назваў дробных геаграфічных аб'ектаў сведчыць пра розную семантыку апелятываў, што ляжаць у іх аснове. Іншымі словамі, у залежнасці ад усходнепалескага рэгіёна мікратапонімы тыпу Драніна маюць розную ўтваральную базу: у Мазырскім Палессі гэта лексема, звязаная з распрацоўкай цаліны, а ў Акцябрскім, Глускім і, магчыма, Петрыкаўскім раёнах - найменне месца нарыхтоўкі дранак.

\section{5. Апелятыў пасёлак}

Яшчэ адной утваральнай базай для некаторых мікратапонімаў Усходняга Палесся паслужыла слова пасёлак, якое абазначае пэўны тып паселішча. Разам 3 тым тыпавыя адметнасці апошняга (у параўнанні з сялом і вёскай) у матэрыялах, што рэпрэзентуюць, напрыклад, лексічны склад мазырскіх гаворак, не адзначаны: 'асобнае паселішча' [Иванова 2007: 152], 'тое, што паселішча (месца, заселенае людзьмі)' [Станкевіч, Воінава, Мінакова 2008: 135], у той час як літаратурны 'населены пункт гарадскога тыпу' [Тлумачальны слоўнік беларускай мовы 1980: 72], відаць, не заўсёды адпавядае мясцовым рэаліям. Як тып паселішча пасёлак адзначаецца на тэрыторыі сучаснай Беларусі 3 другой паловы XIX - першай паловы XX ст. [Лемтюгова 1983: 35]. Само слова, такім чынам, у рэгіёне адносна новае, запазычана 3 рускай мовы [Этыммалагічны слоўнік беларускай мовы 1993: 181], што і абумовіла існаванне невялікай на сённяшні дзень колькасці суадносных з ім айконімаў (паводле даведніка «Назвы населеных пунктаў Рэспублікі Беларусь» - менш за 10 па ўсёй краіне). Што датычыць усходнепалескай тэрыторыі, то сярод адпаведных назваў населеных пунктаў тут адзначаюцца толькі адзінкавыя, прычым страчаныя - 1 айконім у Слуцкім раёне [Назвы населеных пунктаў Рэспублікі Беларусь 2003: 428] і 2 найменні на Гомельшчыне [Назвы населеных пунктаў Рэспублікі Беларусь 2006: 200, 295]. Паводле даных В. П. Лемцюговай, калі апелятыў пасёлак і адпаведны тып паселішча толькі пачалі з'яўляцца ў Віцебскай, Гродзенскай, Мінскай i Магілёўскай губернях, суадносных 3 гэтым словам назваў населеных пунктаў у іх межах яшчэ не было [Лемтюгова 1983, карта № 1].

Іншая сітуацыя з мікратапонімамі: ва Усходнім Палессі яны ўжываюцца значна шырэй, чым айконімы. Гэта звязана, верагодна, 3 тым, што ў адпаведнасці з пастановай ЦК ВКП(б) і СНК СССР ад 27.5.1939 «Аб мерах па ахове грамадскіх земляў калгасаў ад разбазарвання» шматлікія хутарскія гаспадаркі падлягалі ссяленню на пасёлкі [Беларуская энџыклапедыя 2003: 77]. У выніку пачалі з'яўляцца новыя месцы пасялення (у тым ліку, відаць, і ў межах вёсак, у прыватнасці ўсходнепалескіх), якія атрымлівалі, адпаведна, назву Пасёлак. Такім чынам, адзначанае дазваляе гаварыць як мінімум пра два значэнні апелятыва пасёлак: у адным выпадку гэта 
пададзены ў слоўніках літаратурнай мовы населены пункт гарадскога тыпу, у другім - месца пасялення (асобнае або ў межах вясковага населенага пункта), утворанае ў выніку ссялення хутарскіх гаспадарак ці звычайнага перасялення людзей на новае месца жыхарства. Як думаецца, у большасці выпадкаў менавіта другое, у некаторай ступені састарэлае значэнне мела лексема, якая паслужыла ўтваральнай базай для адпаведных назваў дробных геаграфічных аб'ектаў Усходняга Палесся (на гэта ўказваюць і дэнататы шэрагу прыведзеных ніжэй найменняў).

Аднак звяртае на сябе ўвагу тое, што мікратапонімы, суадносныя са словам пасёлак, адзначаюцца ў рэгіёне не паўсюдна. Часцей яны сустракаюцца на тэрыторыі сумежжа слуцкіх і мазырскіх гаворак: Пасёлак частка вёскі (Бабунічы, Чалюшчавічы Петр.), лес (жылі людзі (інфарм.). Хвойня Петр.), Пасёлок частка вёскі (Бобрык, Івашкавічы, Смятанічы Петр.), Посёлок частка вёскі (Людзяневічы Жытк.), Цімошо́ўскі Пасёлак частка вёскі (Мілевічы Жытк.), Жабе́чы Пасёлак завулак (Малыя Гарадзяцічы Люб.); Пасёлак частка вёскі (Лагвошчы Жытк.) [Вярэніч 2009: 396] і інш., у арэале слуцкіх гаворак: Пасёлак частка вёскі (Парэчча Акц., Барбарова, Слаўкавічы Глус.), вуліца (Межылессе Ст.-дар.), Каца́nскі Пасёлак частка вёскі (Кармазы Ст.-дар.); Хітры Пасёлак (Ленькі Слуц.) [Адамовіч 1971: 66], Тры Пасёлкі частка вёскі (уваходзяць тры вуліцы (інфарм.). Вялікая Сліва Слуц.) [Мікратапанімія Беларусі 1974: 238] і інш. Радзей такія найменні адзначаюцца ў арэале мазырскіх гаворак: Пасёлак забалочанае месца (Турбінка Маз.) [Беларуская мова 1996: 167], Пасёлак раён вёскі (4 населеныя пункты) [Иванова 2007: 152], Посёлок Лу́товень пасёлак, дзе раней было поле (Сінкевічы Лун.) [Мікратапанімія Беларусі 1974: 198]. Між тым на Тураўшчыне (паводле апублікаваных матэрыялаў) не выяўлена ніводнага падобнага мікратапоніма - як простага, так і састаўнога. Разам з адсутнасцю фіксацыі ў адзначанай мясцовасці апелятыва пасёлак і суадносных з ім айконімаў, гэты факт можа сведчыць пра тое, што пранікненне адпаведнай рэаліі і яе назвы не закранула гэты ўсходнепалескі рэгіён. Такая нераўнамернасць распаўсюджання на акрэсленай тэрыторыі суадносных 3 указаным словам назваў дробных геаграфічных аб'ектаў і толькі спарадычная фіксацыя на сённяшні дзень лексемы пасёлак указвае, відаць, на рэгіянальныя адрозненні працэсу ўзнікнення такіх месцаў пасялення ва Усходнім Палессі.

\section{6. Заключэнне}

Такім чынам, разгляд шэрагу мясцовых апелятываў праз прызму суадносных $з$ імі мікратапонімаў, якія ўжываюцца на акрэсленай тэрыторыі, дазволіў не толькі ўстанавіць ступень распаўсюджанасці такіх слоў у межах рэгіёна, але і выявіць іх дадатковую семантыку, якая ў большасці выпадкаў не 
адлюстравана ў адпаведнай літаратуры. Гэты факт пацвярджае мэтазгоднасць аналізу назваў дробных геаграфічных аб'ектаў не толькі ў кірунку «ад апелятыва да оніма», але і ў адваротным - «ад оніма да апелятыва», што дапамагае атрымаць больш поўнае ўяўленне як пра сам працэс анімізацыі, так і пра ўмовы яго ўзнікнення і працякання.

\section{Скарачэнні}

\section{Раёны:}

Акц. - Акцябрскі

Глус. - Глускі

Жытк. - Жыткавіцкі

Калінк. - Калінкавіцкі

Лун. - Лунінецкі

Люб. - Любанскі

Маз. - Мазырскі

Нараўл. - Нараўлянскі

Петр. - Петрыкаўскі

Саліг. - Салігорскі

Слуц. - Слуцкі

Ст.-дар. - Старадарожскі

Стол. - Столінскі

Хойн. - Хойніцкі

\section{Iншае:}

інфарм. - інфармант (каментарый ад яго)

памянш. - памяншальная форма

\section{Бібліяграфія}

Адамовіч Яўгеній, 1971, Мікратапанімічныя назвы, Мінск.

Беларуская мова, 1977-1999, вып. 5-20 Мінск, вып. 22-24 Гомель.

Беларуская мова і мовазнаўства, 1973-1976, вып. 1-4 Мінск.

Беларуская эниыклапедыя, 1996-2004, т. 1-18, Мінск.

Выгонная Лилия, 1968, Полесская земледельческая терминология, «Лексика Полесья», Москва, 93-130.

Вярэніч Вячаслаў, 2009, Палескі архіў, Мінск.

Гістарычны слоўнік беларускай мовы, 1982-, т. 1-, Мінск.

Дарошка Мікалай, 1992, Мясцовыя геаграфічныя апелятывы ў мікратапаніміі Тураўскага Палесся, «Беларуская анамастыка», Мінск, 69-94.

Дыялекталагічны атлас беларускай мовы, 1963, Мінск.

Иванова Анна, 2007, Микротопонимия Мозырского Полесья, Мозырь.

Лексіка гаворак Беларускага Прыпяикага Палесся. Атлас. Слоўнік, 2008, Мінск.

Лексічны атлас беларускіх народных гаворак, 1993-1998, т. 1-5, Мінск. 
Лемтюгова Валентина, 1983, Восточнославянская ойконимия апеллятивного происхождения. Названия типов поселений, Минск.

Лемцюгова Валянціна, 1970, Беларуская айканімія. Лінгвістычны аналіз назваў населеных пунктаў Мінскай вобласці, Мінск.

Мікратапанімія Беларусі. Матэрыялы, 1974, Мінск.

Назвы населеных пунктаў Рэспублікі Беларусь, 2003-2010, т. 1-6, Мінск.

Слоўнік мікратапонімаў Магілёучшчыны, 2004, Магілёў.

Станкевіч Аляксандра, Воінава Алена, Мінакова Людміла, 2008, Лексіка народнай гаспадаркі у гаворках Мазырска-Прыпяикага Палесся, Гомель.

Сцяцко Павел, 1977, Беларускае народнае словаўтварэнне. Афіксальныя назоўнікі, Мінск.

Тлумачальны слоўнік беларускай мовы, 1977-1984, т. 1-5, Мінск.

Тураўскі слоўнік, 1982-1987, т. 1-5, Мінск.

Этымалагічны слойнік беларускай мовы, 1978-, т. 1-, Мінск.

Яшкін Іван, 2005, Слоўнік беларускіх мясиовых геаграфічных тэрмінаў: Тапаграфія. Гідралогія, Мінск.

Ossowski Leszek, 1992, Studia slawistyczne, Wrocław.

\section{Vadzim Shkliaryk}

\section{The role of microtoponymy in identifying the semantics of local appellatives (in the material from Eastern Palessie)}

\section{(Summary)}

Cases of a certain discrepancy between the known semantics of a derivational basis and the denotatum of a corresponding proper name are noted while analyzing the names of small geographical objects in the direction "from an appellative to an onym". This may be due to incomplete information about the meaning and semantic nuances of an appellative in local dialects. Therefore, a reverse direction of the analysis, viz. "from an onym to an appellative", is helpful for identifying more amply the semantics of such a word. Considering a series of appellatives from Eastern Palessie is carried out in the article through the prism of microtoponyms correlated with them. It allows to establish the level of occurrence of such words within the region as well as to identify their additional semantics, which is not reflected in the relevant literature in most cases. This fact confirms the appropriateness of analyzing names either in the direction "from an appellative to an onym" or in a reverse direction, i.e. "from an onym to an appellative". It helps to get a better idea both about the process of onymization and the conditions of its emergence and functioning.

Slowa kluczowe: apelatyw, mikrotoponim, semantyka, areał.

Keywords: appellative, microtoponym, semantics, area. 